\title{
DEUTERIUM, TRITIUM AND GROSS-BETA-ACTIVITY INVESTIGATIONS ON ALPINE GLACIERS (ÖTZTAL ALPS)*
}

\author{
By W. Амbach, H. Eisner, M. Elsässer, U. Löschhorn, \\ (Physikalisches Institut der Universität Innsbruck, Innsbruck, Austria)
}
H. Moser, W. Rauert and W. Stichler
(Institut für Radiohydrometrie der Gesellschaft für Strahlen- und Umweltforschung mbH, München, Germany)

\begin{abstract}
By measuring the deuterium contents of stream water, spring water and melt water, as well as ice and snow samples, the mean contributions to melt water in the run-off from Hintereisferner have been estimated: that of melt water being $60 \%$ and that of spring water being $40 \%$ in the months of July to September. Spring water is characterized by very low deuterium contents, whereas ice-melt water and snow-melt water in the summer were found to have about the same, rather high deuterium content. The deuterium content in the run-off was subjected to considerable seasonal fluctuations owing to the changing shares in melt water and spring water. The deuterium contents in individual glacier run-offs show similar seasonal fluctuations and are furthermore characterized by a parallel shift of the deuterium concentrations, because of the different altitudes of catchment areas. Differences in the mean altitudes of catchment areas were estimated for the winter and summer discharges on the basis of the isotope altitude effect.

The seasonal fluctuations of the tritium contents in glacier discharges are caused mainly by the melt water from glacier ice, which contains practically no tritium. Minimum values of tritium content in the runoff were thus found during the period of maximum ice ablation. The mean residence time of the base-flow in the ground-water system of a catchment area was roughly estimated to be a few years on account of the tritium content in the winter run-off and in the precipitations of past years.

Profiles of the gross beta activity in firn cores, despite a reduced atmospheric fall-out during the past years, clearly show activity peaks in summer horizons that are suitable for net accumulation analyses. A characteristic peak in the profile of the tritium content which may be attributed to the net accumulation of
\end{abstract} $1962 / 63$ is well suited for use as a reference horizon.

RÉsumÉ. Investigations sur les teneurs en deutérium, en tritium et l'activité beta brute dans les glaciers alpins (Alpes Otztal). En mesurant la teneur en deutérium des eaux courantes, eaux de sources et eaux de fonte, ainsi que celle d'échantillons de glace et de neige, on a pu estimer la contribution moyenne des eaux de fontes dans les débits issus de l'Hintereisferner: pour les mois de juillet à septembre, celle de l'eau de fusion est de $60 \%$ et celle de l'eau de source de $40 \%$. L'eau de source se caractérise par une très grande pauvreté en deutérium alors que les eaux de fusion de la glace et de la neige ont à peu près la même teneur, assez élevée, en deutérium. Les richesses en deutérium dans l'émissaire sont sujettes à des fluctuations saisonnières considérables en raison des changements des contributions respectives des eaux de source et de fonte. Les teneurs en deutérium des écoulements issus de chaque glacier individuel présentent des fluctuations saisonnières similaires et sont en plus caractérisées par une variation parallèle des concentrations en deutérium selon les différentes altitudes des bassins d'accumulation. Les différences dans les altitudes moyennes des bassins d'alimentation ont été estimées pour les débits hivernaux et estivaux compte tenu de l'effet de l'altitude sur les isotopes.

Les fluctuations saisonnières de la teneur en tritium dans les débits glaciaires résultent surtout des eaux de fonte de la glace de glacier qui ne contiennent à peu près pas de tritium. Les minimum de teneur en tritium dans les écoulements se situent donc pendant les périodes d'ablation maximum de la glace. Le temps moyen de rétention de l'eau du fond dans le système phréatique d'un bassin d'alimentation est approximativement estimé à quelques années, eu égard au contenu en tritium de l'écoulement hivernal et des précipitations des années précédentes.

Des profils de l'activité béta brute dans des carottes de névé montrent clairement, malgré la diminution des retombées radio-actives atmosphériques au cours des dernières années, que les horizons d'été présentent des pointes utilisables pour l'analyse de l'accumulation annuelle. Une pointe caractéristique dans le profil de la teneur en tritium que l'on peut attribuer à la saison d'accumulation i $9_{62}-63$ est bien placée pour constituer un horizon de référence.

Zusammenfassung. Deuterium-, Tritium- und Gesamt-Beta-Aktivitäts-Untersuchungen auf Alpengletschern (Ötztaler Alpen). Aus Messungen der Deuteriumgehalte von Bachwasser, Quellwasser und Schmelzwasser sowie von Eis- und Schneeproben wurden die mittleren Anteile von Schmelzwasser zu $60 \%$ und von Quellwasser zu $40 \%$ im Abfluss des Hintereisferners für die Monate Juli bis September ermittelt. Quellwasser ist durch besonders geringen Deuteriumgehalt gekennzeichnet, während für Eisschmelzwasser und Schneeschmelzwasser im Sommer etwa gleich grosse, jedoch relativ hohe Deuteriumgehalte gemessen wurden. Durch den wechselnden Anteil von Schmelzwasser und Quellwasser im Jahresabfluss ergeben sich grosse

* Paper presented at the International Symposium on Isotopes and Impurities in Snow and Ice, 28-30 August 1975 , organized by the International Commission of Snow and Ice of the International Association of the Hydrological Sciences during the XVI General Assembly of the International Union of Geodesy and Geophysics, Grenoble, France. 
jahreszeitliche Schwankungen des Deuteriumgehalts im Abfluss. Die Deuteriumgehalte einzelner Gletscherabflüsse zeigen untereinander einen ähnlichen jahreszeitlichen Verlauf und auf Grund der verschiedenen Höhenlagen der Einzugsgebiete eine Parallelversetzung der Ganglinien. Mit Hilfe des Isotopenhöheneffekts wurden für Winter- und Sommerabflüsse Differenzen in den mittleren Höhenlagen der Einzugsgebiete abgeschätzt.

Der jahreszeitliche Verlauf der Tritiumgehalte in Gletscherabflüssen ist hauptsächlich durch den Zufluss von Schmelzwasser aus Gletschereis geprägt, da Gletschereis praktisch kein Tritium enthält. Daher zeigen sich Minimalwerte des Tritiumgehalts im Abfluss während der grössten Eisablation. Aus der Abnahme des Tritiumgehalts im Winterabfluss und in den Niederschlägen der letzten Jahre wird die mittlere Verweilzeit des base-flow im Grundwassersystem des Einzugsgebietes abgeschätzt.

Tiefenprofile der Gesamt-Beta-Aktivität im Firn zeigen trotz verringertem atmosphärischen fall-out der letzten Jahre an Sommerhorizonten gut nachweisbare Aktivitätsspitzen, die zu Rücklagenanalysen herangezogen werden können. Ein markanter peak im Tiefenprofil des Tritiumgehalts, welcher der Rücklage $1962 / 63$ zugeordnet werden kann, eignet sich als Bezugshorizont.

\section{i. Area of investigation}

Figure $\mathrm{I}$ shows the sampling sites and the location of the glaciers under investigation: Hintereisferner, Kesselwandferner and Vernagtferner in the catchment area of Rofenache (Ötztal Alps, Austria). This catchment area covers $98 \mathrm{~km}^{2}, 44 \%$ of it being glacierized. Its mean altitude is approximately $2920 \mathrm{~m}$ a.s.l. Characteristic data of the catchment areas and the individual glaciers are reviewed in Table I.

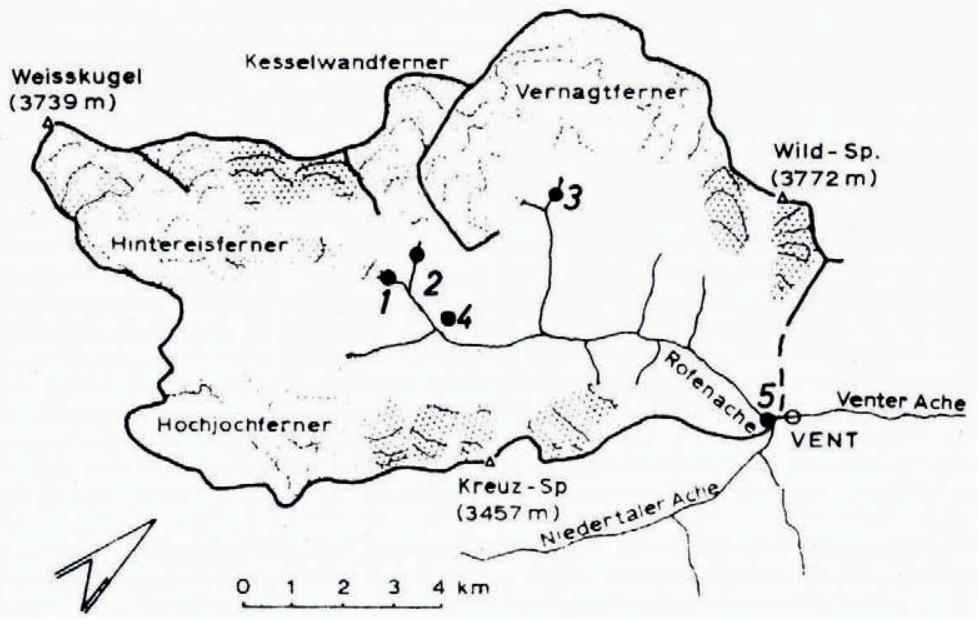

Fig. I. Map of the catchment area of Rofenache (Ötztal Alps, Austria). Sampling sites: $1=$ Hintereisbach (HEB), $2=$ Kesselwandbach $(K W B), 3=$ Vernagtbach $(V B), 4=$ Spring Hochjochhospiz $(H \mathcal{H} H), 5=$ Rofenache, gauge Vent $(R A)$.

Table I. Data on glaciers in the area of investigation: Hintereisferner (HEF), Kesselwandferner (KWF) and VernagtFerner (VF)

\begin{tabular}{|c|c|c|c|c|c|c|}
\hline \multirow[b]{2}{*}{ Glacier } & \multirow[b]{2}{*}{$\begin{array}{c}\text { Glaciated } \\
\text { area } \\
\mathrm{km}^{2}\end{array}$} & \multirow[b]{2}{*}{$\begin{array}{c}\text { Glaciated } \\
\text { part of the } \\
\text { catchment } \\
\text { area } \\
\%\end{array}$} & \multicolumn{3}{|c|}{ Mean altitude above sea-level } & \multirow[b]{2}{*}{$\begin{array}{c}\text { Altitude } \\
\text { of the end } \\
\text { of the glacier } \\
\text { terminus } \\
\mathrm{m}\end{array}$} \\
\hline & & & $\begin{array}{c}\text { of the } \\
\text { equilibrium } \\
\text { line } \\
\text { m }\end{array}$ & $\begin{array}{l}\text { of the } \\
\text { total glacier } \\
\text { area } \\
\mathrm{m}\end{array}$ & $\begin{array}{l}\text { of the } \\
\text { accumulation } \\
\text { area } \\
\mathrm{m}\end{array}$ & \\
\hline HEF* & I 1.2 & $5^{6}$ & 2980 & 3070 & 3155 & 2425 \\
\hline KWF & $4 \cdot 3$ & 75 & 3010 & 3135 & 3175 & 2700 \\
\hline VF & 9.5 & 85 & 3080 & 3175 & 3180 & 2700 \\
\hline
\end{tabular}

* Plus smaller glaciers in the catchment area proper. 


\section{ISOTOPE CONTENT IN SAMPLES OF SNOW, ICE AND RUN-OFF}

\subsection{Introduction}

Measurements of the concentration of deuterium, oxygen-18 and tritium in samples of snow, ice and stream water from a glacierized catchment area have already been used in previous studies for determining the shares of melt water from snow, melt water from ice, and subglacial spring water, in the discharge of a glacier stream during the summer ablation period (Behrens and others, I97I). This was possible, because of the low deuterium concentrations in spring water compared with those in melt water from snow and ice. Furthermore, melt water from old glacier ice contains no tritium at all. By measuring only deuterium and not tritium, it is not possible to distinguish between melt water from snow and ice during the summer ablation period, as the deuterium concentrations are approximately equal in both types of melt water. To distinguish between these two melt water contributions, the tritium concentrations must be measured additionally (Ambach and others, 1973). In general, simultaneous measurements of deuterium and oxygen-1 8 concentrations give no further information on the proportions of melt water and spring water in a glacier stream.

The wide range of variations in deuterium concentrations that occur in every individual precipitation is reduced considerably by metamorphosis of the snow cover and by mixing processes in the run-off system of glaciers. The final values obtained for melt water, stream water and spring water are mean deuterium concentrations with small ranges of variation of the respective samples, but significant differences, from which the relative shares of melt water and spring water in the total run-off of the glacier stream can be determined for a summer ablation period.

In the present paper the changes in isotope content from precipitation to run-off, and the related glacier-hydrological effects are discussed.

\subsection{Isotope content in the precipitation and in the snow cover}

Figure 2 shows the deuterium content* in the samples taken from individual precipitation events at Vent (Fig. I). The values plotted as a step function (solid line) are weighted monthly mean values of the deuterium content in the precipitations. The diagram shows on the one hand the typical annual variations with high values in the summer and low values in the winter, on the other hand the great fluctuations between successive precipitation events having the wide range of annual fluctuations. The variations in the isotope content observed during one individual precipitation event are almost as high as the annual variations (Ehhalt and others, 1963; Bleeker and others, 1966; Ambach and others, 1975).

The individual layers of the winter snow cover can in general be well correlated to the mean isotope contents of successive periods of precipitation (Moser and Stichler, 1975). In general, the snow surface shows enrichment of heavy isotopes, deuterium and oxygen-I8 caused by fractionation processes during phase transitions (Judy and others, 1970; Moser and Stichler, 1970; Moser and Stichler, 1975).

\subsection{Range of variation of isotope contents in samples of snow, ice and water from a glaciated catchment area as exemplified at Hintereisferner}

Figure 3 shows individual measurements of the deuterium content in samples of snow, snow-melt water, ice, ice-melt water, spring water and stream water taken during the ablation periods of 1969,1970 and 1971 . They show clearly a decrease in the range of variation from the snow samples $(-45 \%$ to $-160 \%$ ) followed by the ice samples $(-90 \%$ to $-125 \%$ ), the ice-melt water samples $(-90 \%$ to $-110 \%$ ) and the creek samples $(-100 \%$ to $-115 \%$ )

\footnotetext{
$1961)$.

* The deuterium content is given by the $\delta D$ value, the relative deviation from the standard SMOW (Craig,
} 

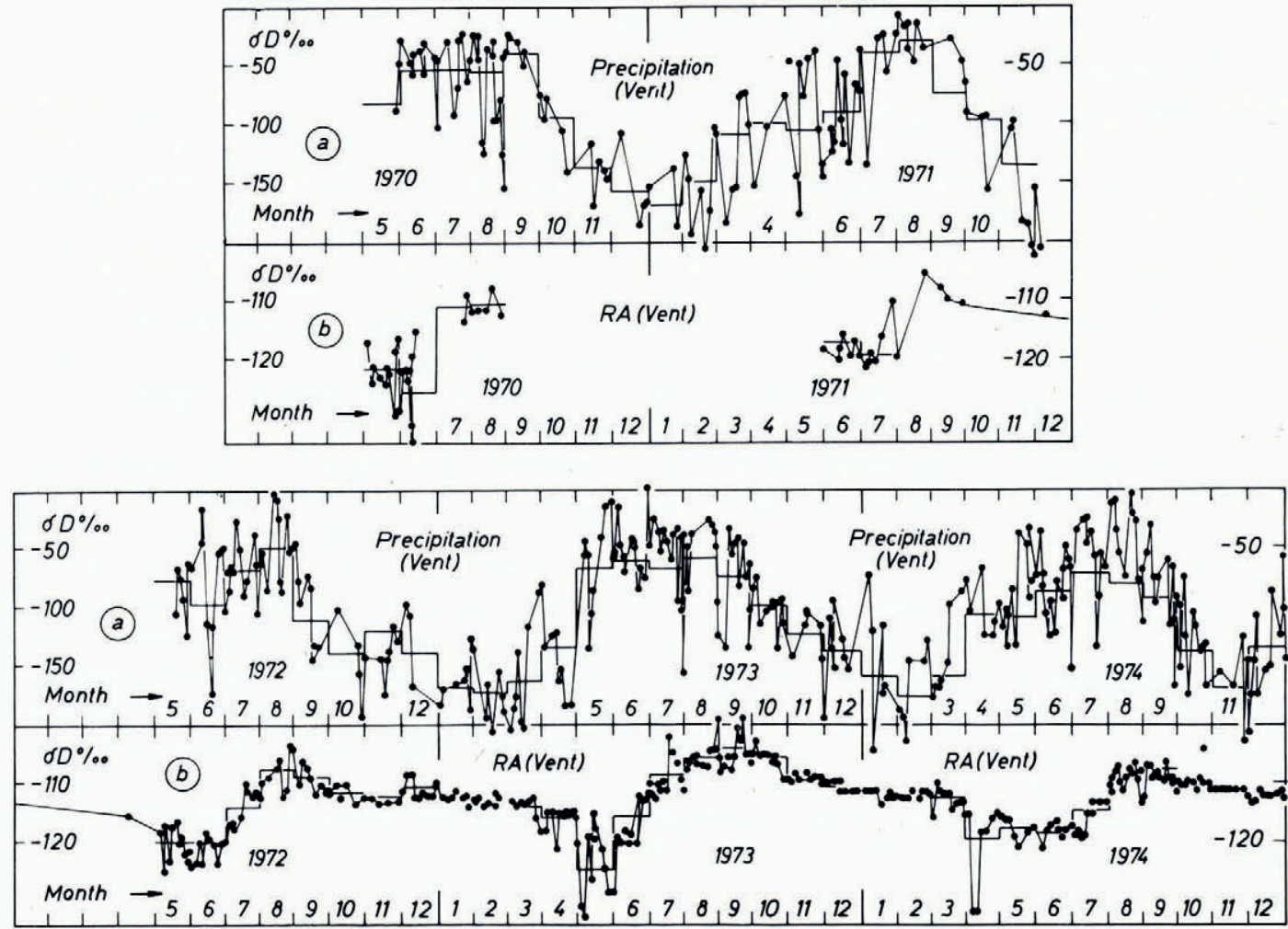

Fig. 2. Seasonal fluctuations of the deuterium concentration at Vent (cf. Fig. I).

(a) Precipitation, Vent: dots correspond to individual precipitations, the step function giving the weighted monthly mean value;

(b) Water samples Rofenache $(R A)$, Vent: dots correspond to individual samples, the step function giving the unweighted monthly mean value.

The double standard deviation of the $\delta D$ values is $1 \%$.

(Table II). This homogenization doubtlessly is largely due to mixing in the drainage system of the glacier. Processes of fractionation between percolating melt water and firn also cause homogenization accompanied by an enrichment of heavy isotopes. This has been shown earlier on drill cores from the accumulation area of Kesselwandferner in which homogenization of the ${ }^{18} \mathrm{O}$ content was clearly observed in depths between $8 \mathrm{~m}$ and $\mathrm{I}_{5} \mathrm{~m}$, the maximum depth of drilling (Ambach and others, 1972). Although the percolation of melt water during several months hardly changes the profile of isotope content of a snow cover (Moser and Stichler, I 975), long-term percolation of a firn layer must be assumed to have a homogenizing effect on the profile of isotope content.

The difference between the mean value of the deuterium content in spring water and that of snow and ice samples may be caused by fractionation processes during ice formation, but also by preferred alimentation of the springs by melt water from winter precipitation with low deuterium concentration. The mean value of the deuterium content of the glacier run-off, being a mixture of melt water and spring water, lies between the deuterium concentrations of the two run-off components. Furthermore it may be seen that the range of variation in deuterium contents of the spring waters is small and corresponds approximately to that of the samples of melt water from ice and stream water. 


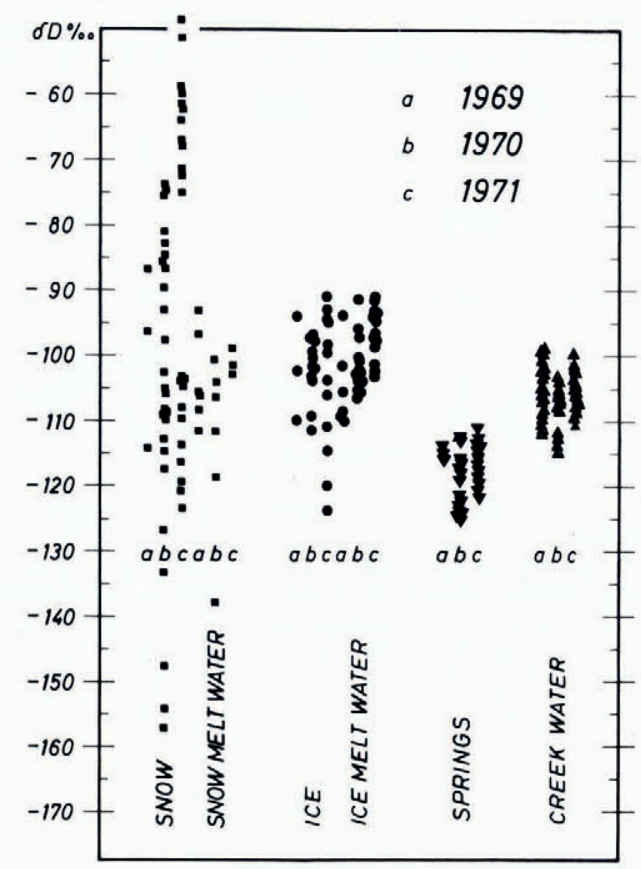

Fig. 3. Deuterium content of snow, melt water from snow. ice, melt water from ice, spring water and stream water of Hintereisferner. The samples were taken in July, August, and September of 1969 to 1971 .

TABle II. RANGE OF VARIATION AND MEAN VALUES OF THE DEUTERIUM CONTENTS OF SAMPLES FROM SNOW, MELT WATER FROM SNOW, ICE, MELT WATER FROM ICE, SPRING WATER AND STREAM WATER OF HINTEREISFERNER

The samples of snow, melt water from snow, ice, melt water from ice were collected in the summer months of the years 1969 to 1971 , samples of spring water and stream water were collected July to September $1969-74$.

Range of variations $\Delta \delta D$

Mean values $\delta D$
Mean values of sample groups $\delta D \%$

Number of samples

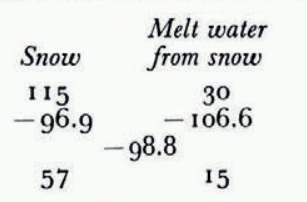

$\begin{array}{ll}\text { Spring } & \text { Stream } \\ \text { water } & \text { water }\end{array}$

$\begin{array}{cc}15 & 15 \\ -116.0 & -106.6 \\ -116.0 & -106.6 \\ 43 & 76\end{array}$

\subsection{Annual variations of the deuterium content in the run-off from three glaciers and in the Rofenache}

Figures 4-6 show the variation of the deuterium content of individual samples taken over a period of several years from the glacier streams of Kesselwandferner, Hintereisferner and Vernagtferner in the catchment area of Rofenache and from Rofenache at Vent. For comparison, Figure 7 gives the corresponding variations for the spring at Hochjochhospiz $(\mathrm{HJH})$ from the same catchment area.

At the beginning of the melting period (April to June), the deuterium content drops considerably down to a minimum (Figs 4-6). This is due to the direct run-off of melt water from snow layers located in the lower region of the glaciated catchment area as well as in the nonglacierized catchment area, the snow being accumulated during the winter at low temperatures, thus showing low deuterium concentrations. Shifts of the negative peak in the deuterium concentration depend on the ablation conditions in the months of April to June. The occurrence of such a negative peak in the graph for the Hochjochhospiz spring shows that this spring also contains a considerable share of melt water from winter precipitation running off directly during this period (Fig. 7). 

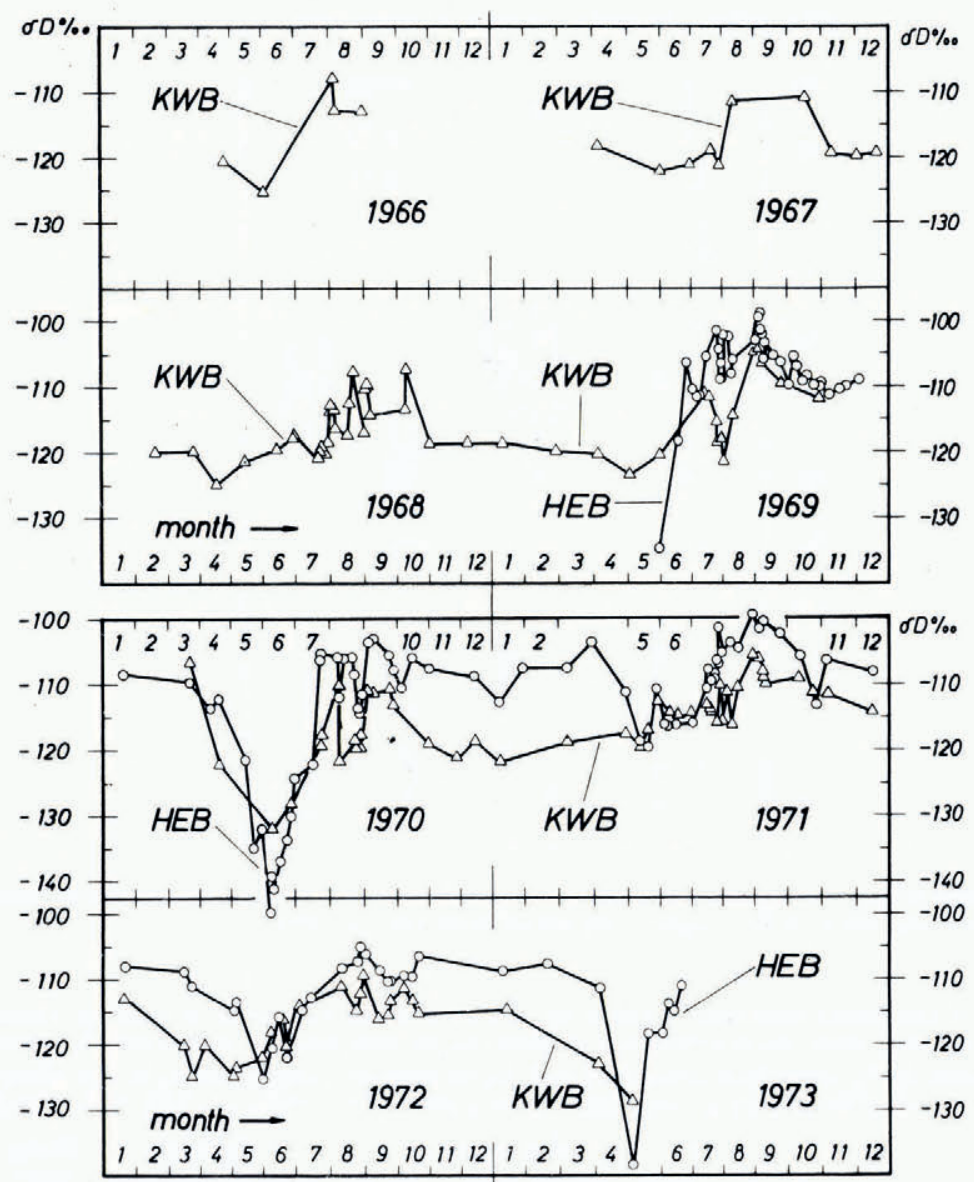

Fig. 4. Seasonal variation of the deuterium content $\delta D$ in the run-off of Hintereisferner $(H E B)$ and Kesselwandferner $(K W B)$ in the years 1966 to 1973.

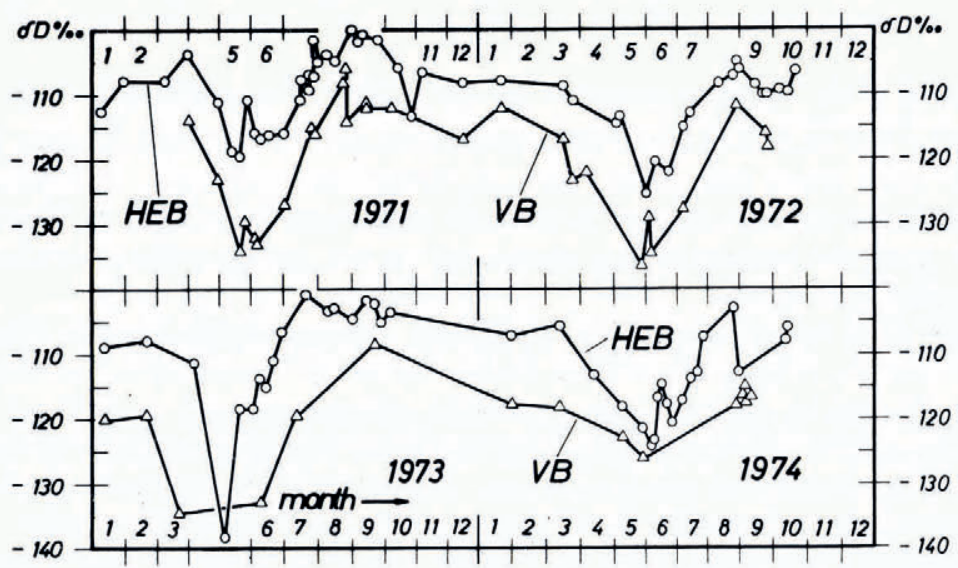

Fig. 5. Seasonal variation of the deuterium content $\delta D$ in the run-off of Hintereisferner $(H E B)$ and Vernagtferner $(V B)$ in the years 1971 to 1974 . 


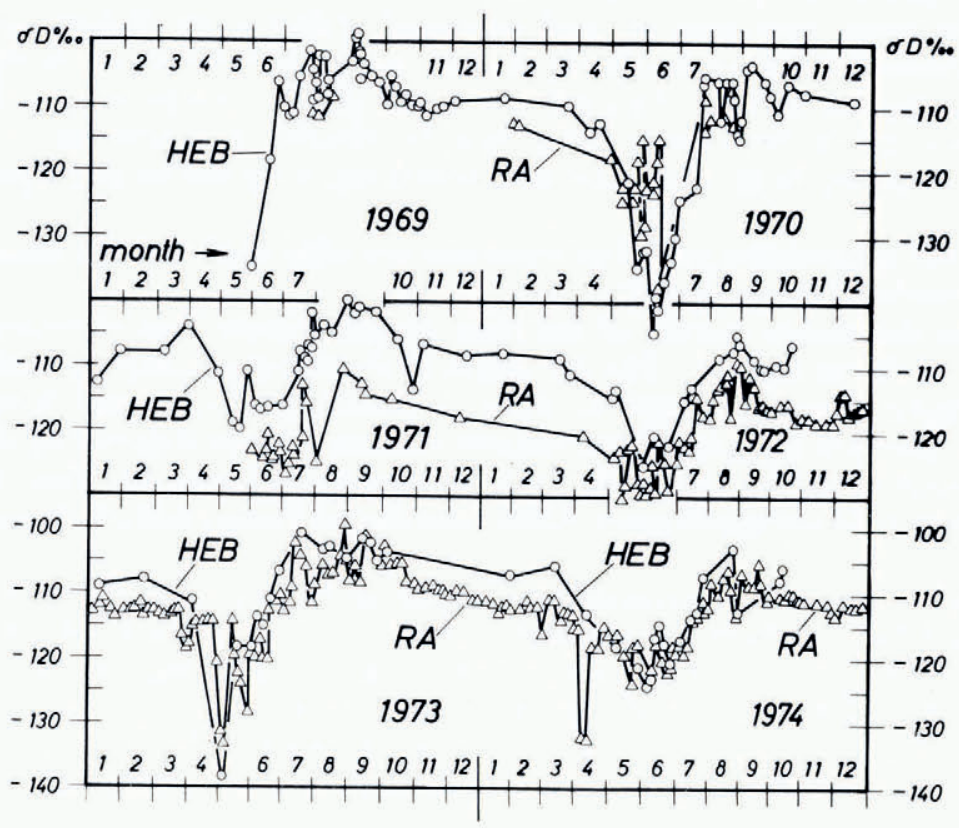

Fig. 6. Seasonal variation of the deuterium content $\delta D$ in the run-off of Hintereisferner $(H E B)$ and Rofenache (RA) in the years 1969 to 1974 .

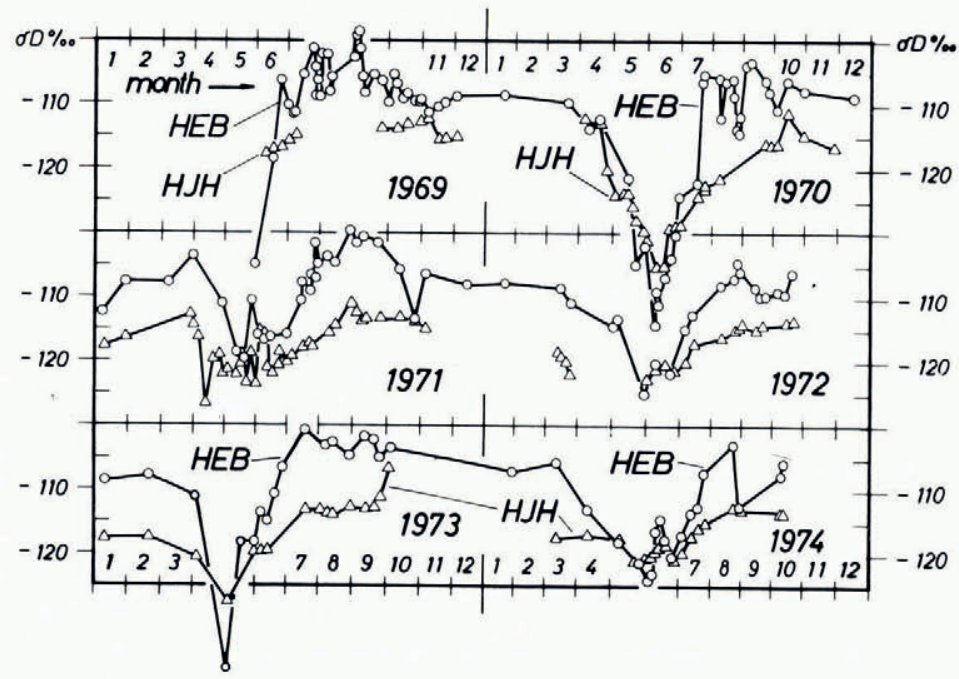

Fig. 7. Seasonal variation of the deuterium content $\delta D$ in the run-off of Hintereisferner $(H E B)$ and the spring of Hochjochhospiz $(\mathrm{HJH})$ for 1969 to 1974 . 
In the summer ablation period (July to September), the variation in deuterium content in glacier streams is governed by the different deuterium contents of the individual run-off shares (melt water from snow and ice, and subglacial spring water, Behrens and others, I97 I). The deuterium contents of the glacier streams as well as those of the Hochjochhospiz spring increase during this period. This increase in the glacier streams on the whole is due to the run-off of isotopically heavy melt water from the ablation area, whereas in the case of the Hochjochhospiz spring the ground water discharge is superimposed on direct precipitation discharge.

During the winter accumulation period the variations are only small-in the glacier streams as well as in the Hochjochhospiz spring.

Comparing the deuterium content of the three glacier streams and Rofenache we find annual variations of the same kind. The $\delta D$ values of the Hintereisferner run-off, however, are somewhat higher, though parallel to those of Kesselwandferner and Vernagtferner. This is due to the different altitudes of the catchment areas. Figure 8 shows the distribution in altitude of the areas of the three glaciers. Table I gives some characteristic data: the altitude distribution of Hintereisferner significantly differs from that of Kesselwandferner and Vernagtferner.

Table III reviews the mean deuterium contents during the three run-off periods of winter, spring and summer for the three glaciers and for Rofenache. The limits of the individual periods were determined by the following conditions: the spring period (or summer period) shows the deuterium concentrations of individual samples to be smaller (higher) than the mean value of the winter run-off of the respective year (decrease in the deuterium content in spring is caused by the snow melt; increase in the summer is due to ice ablation, cf. Figs $4^{-6}$ ).

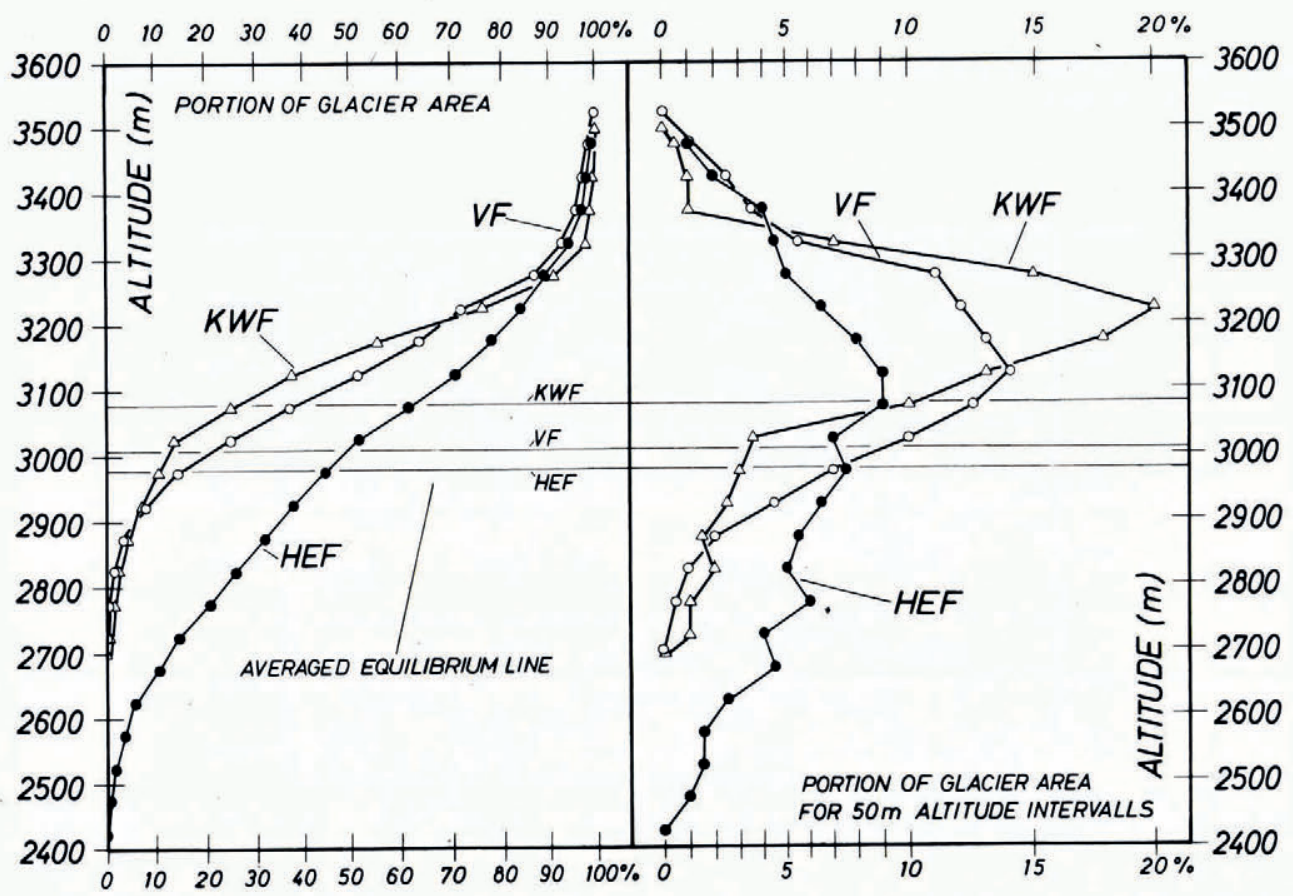

Fig. 8. Altitude distribution of the glacier area for Hintereisferner $(H E F)$, Vernagtferner $(V F)$ and Kesselwandferner $(K W F)$ and the altitude of the averaged equilibrium line. Right: fraction of glacier area per $50 \mathrm{~m}$ altitude interval. Left: integrated altitude distribution curve. The results for Hintereisferner and Vernagtferner were taken from Reinwarth (1972), results for Kesselwandferner were kindly made available by $H$. Hoinkes. 
Table III. Mean values of the deuterium content $(\delta D)$ in the run-off of Hintereisferner (HEB), VernagtFerner (VB), Kesselwandferner (KWB) AND THE SPRING HochjochHospiz (HJH), AS WELl aS ROFENACHE (RA) IN THE WINTER, SPRING AND SUMMER PERIODS (COLUMN)

For an explanation of the time limitation of the seasons see text. In $\mathrm{HJH}$, the winter covers a period from November to March, spring from April to June, summer July to September. Wherever possible, the differences in the mean deuterium contents $\Delta \delta D$ (of $\mathrm{VB}, \mathrm{KWB}, \mathrm{HJH}$ and $\mathrm{RA}$ ) as compared to $\mathrm{HEB}$ are given.

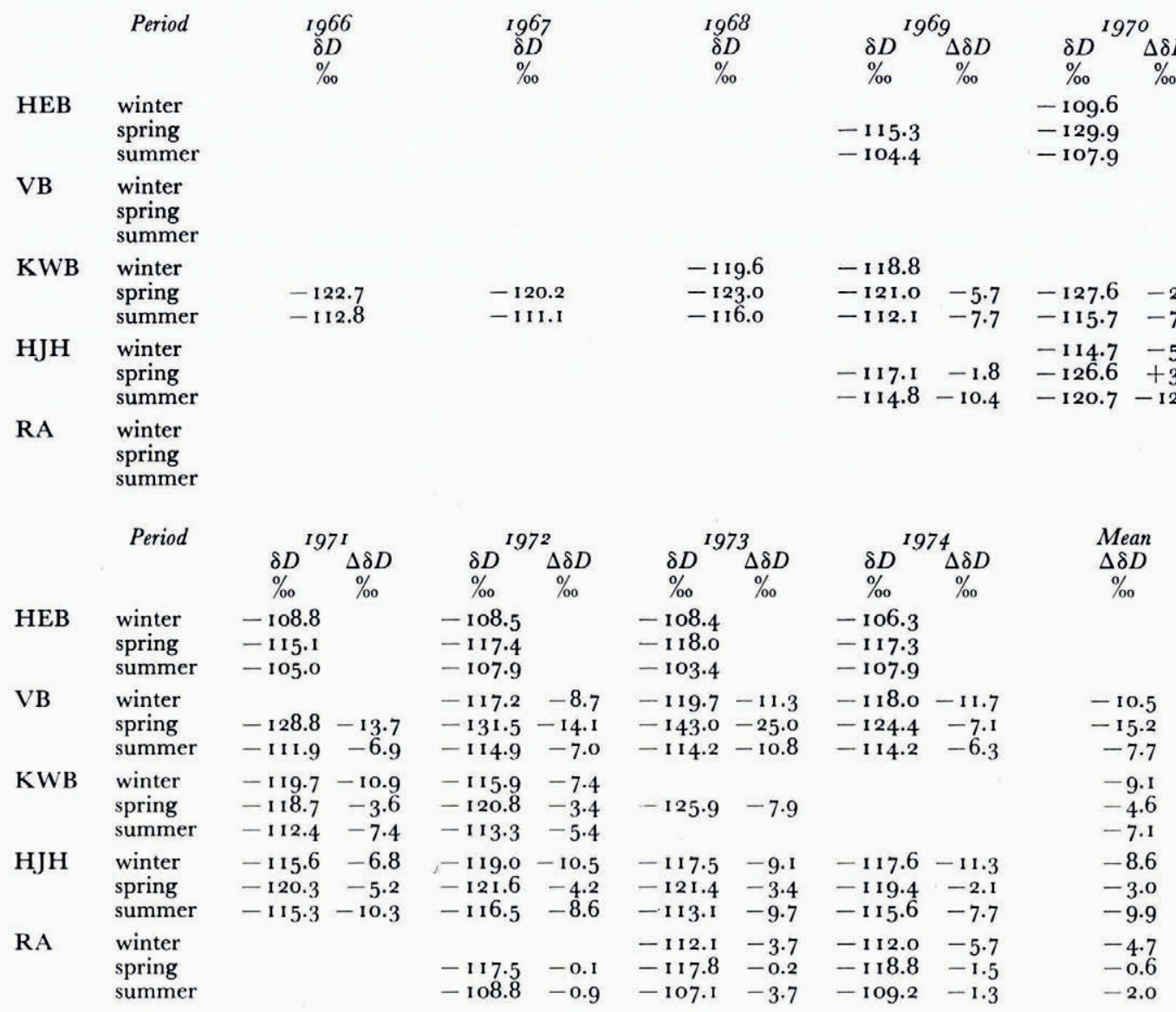

The mean values of deuterium contents given in Table III are about $10.5 \%$ and $9.1 \%$ o lower for the winter run-off of Vernagtferner and Kesselwandferner, respectively, than are the values for the winter run-off of Hintereisferner. For the summer ablation period, the corresponding values are $7.7 \%$ and $7.1 \%$, respectively. Comparing successive years, the mean deuterium concentration differs significantly for the snow-melt period in spring, the mean values of the deuterium concentration of Vernagtferner being especially low.

From the significant parallel shift in the graphs for annual fluctuations of deuterium content in glacier run-off (Figs 4-6) conclusions are made as to differences in the mean altitudes of the catchment areas using the isotope altitude effect. In view of an isotope altitude effect in precipitation of about $-3 \%$ per $100 \mathrm{~m}$ (cf. Moser and Stichler, 1970), the conclusion follows that the catchment areas of the winter discharge of Vernagtferner and Kesselwandferner on average are about $300 \mathrm{~m}$ higher than that of Hintereisferner. The difference in altitude calculated for the summer discharge is only about $250 \mathrm{~m}$. The corresponding catchment areas of Vernagtferner are somewhat higher than those of Kesselwandferner. 
Under the same assumptions, the isotope altitude effects of Rofenache and of Hintereisferner indicate that the mean total catchment area of Rofenache in the winter is about $150 \mathrm{~m}$ higher than that of Hintereisferner. During the summer ablation period this difference in altitude is reduced by $50 \%$.

The fact that the altitude of the catchment area of Rofenache was found to be higher for the winter run-off and the summer run-off than the catchment area of Hintereisferner confirms the high contribution of Kesselwandferner and Vernagtferner run-off in the discharge of Rofenache. Due to local variations and variations in time of the altitude effect as well as to differences in deuterium data of successive years (Table III), the results on the altitude differences in catchment areas are not definite. However, the differences in the mean altitudes of glacier areas of Table I are smaller than those for the entire catchment areas obtained from the isotope analysis.

On account of the highly glacierized catchment area, the seasonal changes in deuterium content of Rofenache. (Fig. 6) are similar to those of the individual glacier run-off. The $\delta D$ values of the individual samples from Rofenache vary between $-100 \%$ and $-130 \%$, the monthly means being between $-105 \%$ and $-125 \%$. Remarkable is the highly constant isotope content which is repeatedly observed in the winter run-off. The mean values for the winter months of 1973 and 1974 are $-112.0 \%$ and $-\mathrm{I}_{12} 2.1 \%$, respectively. The fluctuations in $\delta D$ values of Rofenache characterize very well the onset of snow ablation by a drop in deuterium content. The transition from ablation of winter snow to ice ablation is marked by an increase in $\delta D$ values. The beginning of winter run-off is characterized by an approximately constant deuterium content. In Table IV, the time sequence of these characteristic

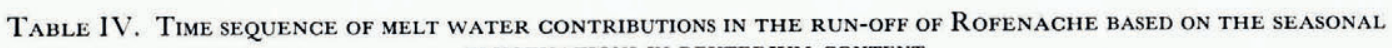
FLUCTUATIONS IN DEUTERIUM CONTENT

Year
$1972 / 73$
$1973 / 74$
$1974 / 75$

Period with a great share in melt water from winter snow May, June March, April, May April to beginning of July

\section{Transition from snow to ice ablation July} middle of June to July July to August

\section{Period with a large fraction of melt water from glacier ice}

August September September
Winter run-off

October to February December to March November onward

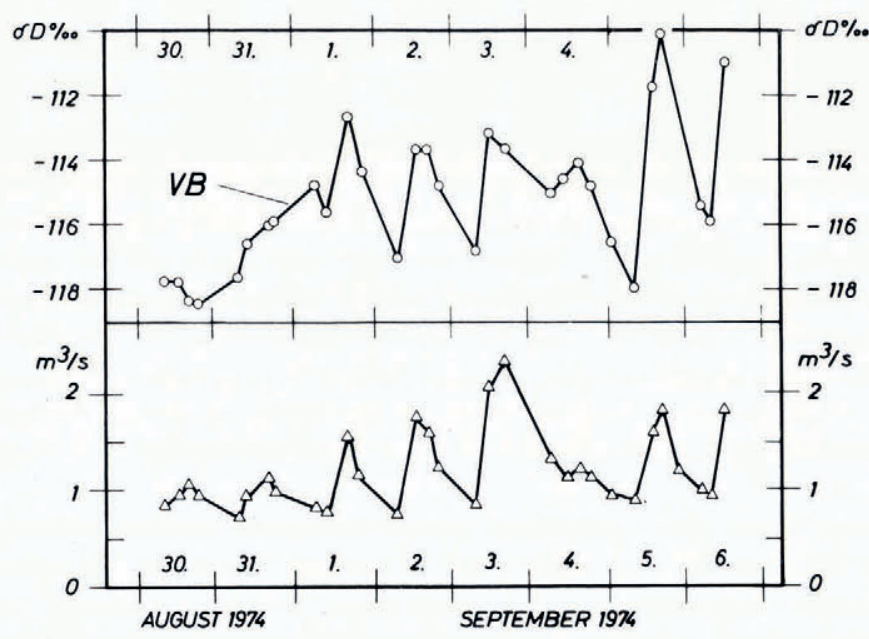

Fig. 9. Daily variations of the deuterium content $\delta D$ and the discharge of Vernagtferner $(V B)$ for the period from 30 August 1974 to 6 September 1974. Data on discharge were kindly made available by O. Reinwarth. 
run-off periods is reviewed for the years $1972-74$. The values were obtained from the variations in deuterium concentration. The relation between the daily variations of deuterium content and the discharge observed for Hintereisbach during a mid-summer ablation period by Behrens and others (I97I) was confirmed. As a further example, Figure 9 shows the variations in deuterium content of Vernagtbach during eight days of measurements. Evidently, the deuterium content increases and decreases in phase with discharge. This confirms the result that the melt-water flow on the glacier surface during periods of high ablation rate directly from the glacier surface contains more deuterium than the base flow. However, the high $\delta D$ values on 5/6 September 1974 are due to melt water from a thin snow cover (snow fallen during the night of 3 to 4 September 1974), which melted with a delay because of the cool weather on 4 September 1974 .

\subsection{Mean proportions of melt water running off directly and of spring water in the discharge of Hintereis- ferner for the months of July to September}

Table II contains the mean deuterium concentrations of stream water, spring water, ice-melt water and snow-melt water, and also of ice samples and snow samples. The individual values of the years $1969-71$ are presented in Figure 3. From it, the following characteristics are obtained:

The variation in the $\delta D$ values of snow samples is very wide, varying between $-50 \%$ and $-160 \%$.

The mean value of the deuterium concentration of $-98.8 \%$ in the group of snow plus snow-melt water samples is very close to that of the group of ice plus ice-melt water samples $(-100.7 \%$ ). Hence it follows that it is not possible to distinguish between ice-melt water and snow-melt water during the summer months by measuring the deuterium content.

The mean values of deuterium concentrations of spring water, melt water (from ice and snow) and stream water differ significantly, showing small ranges of variation of the respective examples. It is therefore possible to calculate the discharge contributions of melt water and spring water in the total discharge from the deuterium concentrations of stream water.

For calculating the discharge shares of melt water and spring water in the total discharge, the following values were used from Table II :

Mean deuterium concentration of stream water for the months of July to September: $-106.6 \%$.

Mean deuterium concentration of spring water: $-116.0 \%$.

Mean deuterium concentration of melt water: $-100.7 \%$.

From these data the mean contribution of melt water to the Hintereisferner discharge was found to be $60 \%$ and that of spring water $40 \%$. Thereby it was assumed that the $\delta D$ values of the base flow are equal to those of the spring water during the sampling period. The result obtained by averaging the $\delta D$ values over the months of July to September is in good agreement with the contributions determined for individual days of the ablation period by Behrens and others (197I). Measuring the tritium concentration in the midsummer ablation period, Ambach and others (1973) also found the proportion of melt water from the ablation area of Kesselwandferner to be $31 \%$ during the night hours and $57 \%$ during day-time as minimum and maximum values, respectively. Melt water from snow was not considered in these values.

The assumption that the mean $\delta D$ value for melt water is $-100.7 \%$ is explained as follows: Table II shows that the mean values of the deuterium concentrations in the samples of snow, snow-melt water, ice, and ice-melt water are not significantly different. Because of the small range of variation in $\delta D$ values of the group of ice plus ice-melt water samples, this value 
appears as being better supported than the value of the group of snow plus snow-melt water samples. It thus seems to be justified that the $\delta D$ value of the group ice plus ice-melt water samples may be taken for that of melt water, irrespective of its origin (ice or snow). It is easy to understand that the difference in the mean values of the groups of snow plus snow-melt water samples $(-98.8 \%)$ and ice plus ice-melt water samples $(-100.7 \%)$ is small, because the ablation area copies the accumulation area on account of rheological processes, the ice of the ablation area originates from precipitation deposited in the accumulation area. In the present case it cannot be proved statistically that the deuterium content in melt water from ice is higher than that in melt water from snow, although it is assumed that metamorphosis from snow into firn and secondly into ice must effect a change because of the fractionation processes mentioned in section 2.3. Deuterium concentration of snow-melt water differs significantly from that of ice-melt water only in special cases, e.g. if the melt water from new snow in summer occurs with high deuterium concentrations.

\subsection{Time variation of tritium content in the discharge of Hintereisferner and in Rofenache}

Figure 10 shows the seasonal variations of tritium contents in the Hintereisferner discharge and in Rofenache. The curves have a shape similar to that of stream samples from the Rofenache catchment area published earlier (Ambach and others, 1973; Behrens and others,
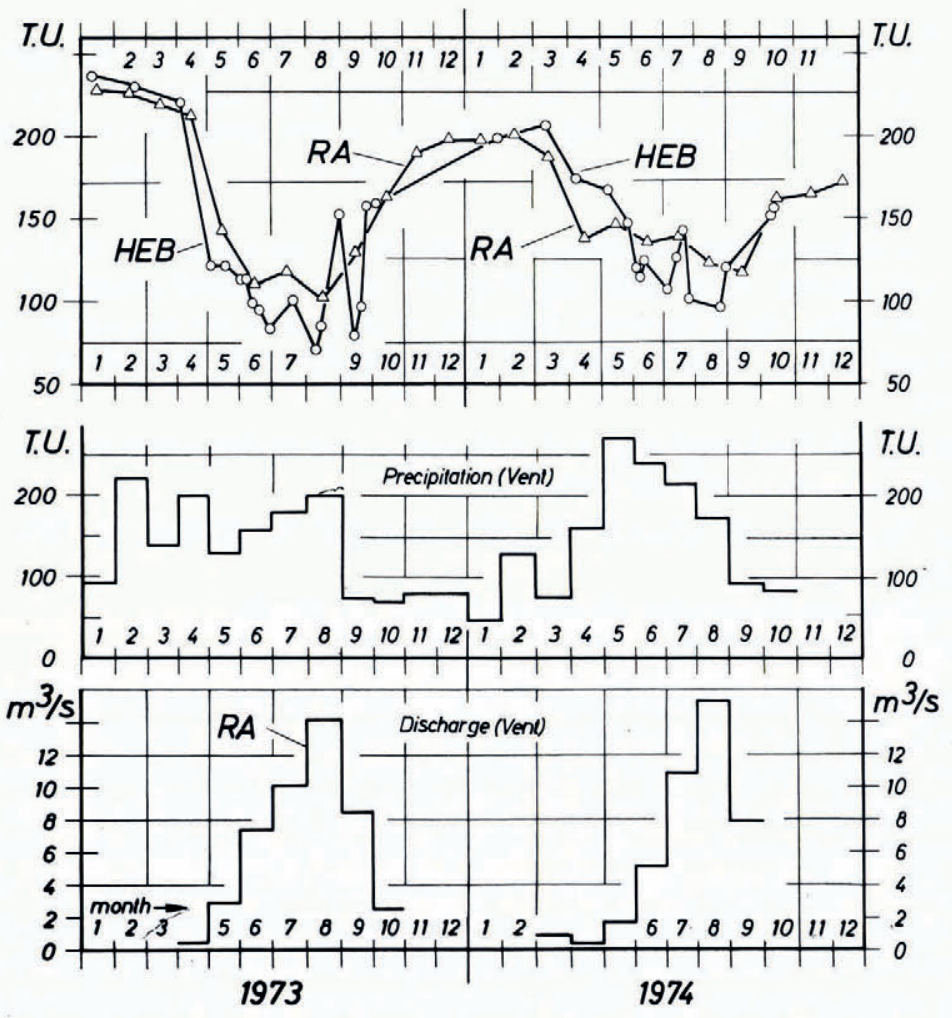

Fig. 10. Upper section: Seasonal variation of the tritium content in the run-off of Hintereisferner (HEB; individual samples) and Rofenache (RA; unweighted monthly mean) in the years 1973 and 1974 . The double standard deviation of the measured values is 9-13 T.U. at maximum. Middle section: Seasonal variations of the tritium content in precipitation samples, Vent, weighted monthly means. Bottom section: Monthly means of discharge of Rofenache (gauge at Vent). (The Hydrographischer Dienst, Innsbruck, is thanked for supplying the measured discharge data.) 
1971). There the minima in tritium contents in midsummer are explained by maximum shares of melt water from glacier ice that.is practically free of tritium. The reduction in tritium content of the discharge during spring is due to the low tritium content in the melt water from winter snow. A similar decrease in tritium content at the onset of winter snow melting has been found in the run-off of the Dischma basin (Switzerland) by Martinec and others (1974) where it is limited, however, to the period of snow melt. There, however, it never reaches the minimum in tritium contents observed in the glacier streams of Rofental, because the Dischma basin is hardly glaciated-in contrast to the catchment area of Rofenache.

The curves of variation for the tritium contents of run-off from Hintereisferner and Rofenache are similar. However, the summer values in the Hintereisferner run-off are lower than in Rofenache (Fig. IO). In accordance with the daily variations in tritium content given by Behrens and others (197 I), this shows that Hintereisbach during the ablation period has a greater proportion of melt water than Rofenache.

In consequence of different ablation conditions which are reflected by the difference in tritium contents in the run-off, ice ablation in the summer 1974 began later than in 1973 . This has already been observed in the time variation of the deuterium content in the Rofenache run-off (Table IV) and may furthermore be confirmed by comparing the minima of tritium contents of Figure 1o which correspond to highest proportion of ice-melt water. Figure 1o also contains the tritium concentrations in the precipitation at Vent. The values are plotted as the weighted monthly means. Significant seasonal fluctuations are shown as well as the high values of spring 1974. The increase of tritium contents in spring 1974, however, is in agreement with the tritium increase observed in precipitation in other parts of Austria in May and June I974 which were also higher than the year before (Bauer and others, 1975). Figure Io furthermore shows the monthly means of the Rofenache discharge (Vent) illustrating the relation between high discharge due to strong ablation and low tritium concentrations.

Maximum tritium contents are always observed in the winter discharge. Figure I I gives the decrease in these maximum tritium contents for the years of $1968-74$ (Fig. Io and Behrens and others, 1971), as well as the annual means of tritium concentrations in the precipitations of various stations. All precipitation values are below the tritium contents in the respective winter run-offs (Fig. I0), if the annual mean values of the tritium content in the precipitation are taken as an approximate measure of the tritium input concentrations in the ground water system of the catchment area. It may be concluded that the winter discharge is being fed by water of precipitations of former years, containing more tritium. Martinec and others (1974) have conducted model calculations for the Dischma basin, on the basis of which the mean

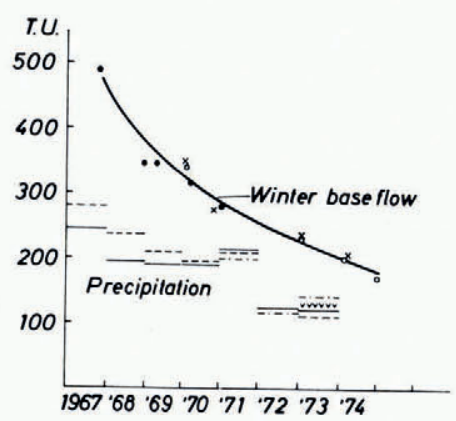

Fig. II. Decrease in tritium content in the winter run-off of Kesselwandferner $(\kappa W B)-1$, Hintereisferner $(H E B) \times$, and Rofenache at Vent $(R A) \bigcirc$, and decrease in precipitation at Hohenpeissenberg (Bavaria) - - - - . Petzenkirchen (Austria) - Wien---, and Vent (Austria) vvv. Curve drawn by estimation. (IAEA, 1971, 1973) Gratitude is expressed for the private information on measured data by the Isotope Hydrology Section of the IAEA. Wien. 
residence time of the ground-water share in the discharge was estimated to be approximately four to five years. The models assumed for calculating the age distribution were the "exponential model" and the "dispersion model" with a ratio of $2 / 3$ of winter recharge and I/3 of summer recharge. The differences found between the two models were small.

A comparison with the results measured in the catchment area of Rofenache suggests that the residence times for the water of base-flow in the winter are similar. This, however, does not explain whether the base-flow originates mainly from melt water of long intraglacial storage or from the ground-water reserve of the soil.

It may thus be concluded that new information can be obtained on the proportions of melt water and spring water in the total discharge and on the residence time of the base-flow in the ground-water system of an Alpine glacier by measuring the contents of deuterium and tritium on samples from a glaciated catchment area.

3. Vertical profiles of the Gross beta aCtivity and tritium CONTENT in the ACGUMUlaTION AREA OF KESSELWANDFERNER FOR DETERMINING THE ANNUAL NET ACGUMULATION

\section{I. Introduction}

The pattern of the annual net accumulation in the accumulation area of Alpine glaciers have so far been determined by measuring vertical profiles of the gross beta activity only for periods of heavy atmospheric fall-out (Eisner, 1971). Because of the much lower radioactivity measured in air and precipitation samples during past years, it was doubtful if these methods were still applicable, especially as the role of natural radionuclides in the formation of activity horizons is still largely unknown. The present examination is intended to show whether the gross beta activity also yields characteristic vertical profiles in the accumulation area of Kesselwandferner during periods with comparatively low atmospheric fall-out (1966-73), and above all whether the summer melt horizons are clearly marked by activity peaks.

\subsection{Results}

In the accumulation area of Kesselwandferner, two drillings (I, II) down to about I $2 \mathrm{~m}$ depth have been made with a SIPRE drill that had been improved by Eisner (1971). The drill core was cut into samples about 5 to $10 \mathrm{~cm}$ long, and the gross beta activity of the dry residue after evaporating the samples was measured with a low-level counter (background about 2 counts per minute). The sample preparation has been described in detail by Url (unpublished) and Elsässer (unpublished). The annual net accumulations from I966 to 1973 were determined by means of the vertical profiles of the measured gross beta activity given in Figure 12. Good agreement was observed with results obtained independently from stake readings and determinations of water equivalents (Elsässer, unpublished).

While the firn activities of the summer horizons $196 \mathrm{I}-64$ varied between 85 and 546 $\mathrm{pCi} / \mathrm{kg}$ (Eisner, I97I) - they were caused by heavy atmospheric fall-out - the activity values of the summer horizons of $1966-73$, though well above the limit of identification, were no more than 6-69 pCi/kg.

Between the respective annual horizons there occur low gross beta activities with values smaller than $5 \mathrm{pCi} / \mathrm{kg}$, as has been observed also by Eisner (1971). The decrease in horizon activities of the period of 1966 to 1973 as compared to that of 1961 to 1964 by approximately a factor of 10 is in good quantitative agreement with the decreasing gross beta activity of precipitation samples during this period (Fig. 13).

The activity peaks of the period 196 I to 1964 are around $3000 \mathrm{pCi} / \mathrm{l}$; those of the period of 1966 to 1973 are around $285 \mathrm{pCi} / \mathrm{l}$ at a maximum. The maximum values of the gross beta activity of air samples are lower in the period I966 to 1973 than between 1961 and I964 (when they were 20 times higher). 

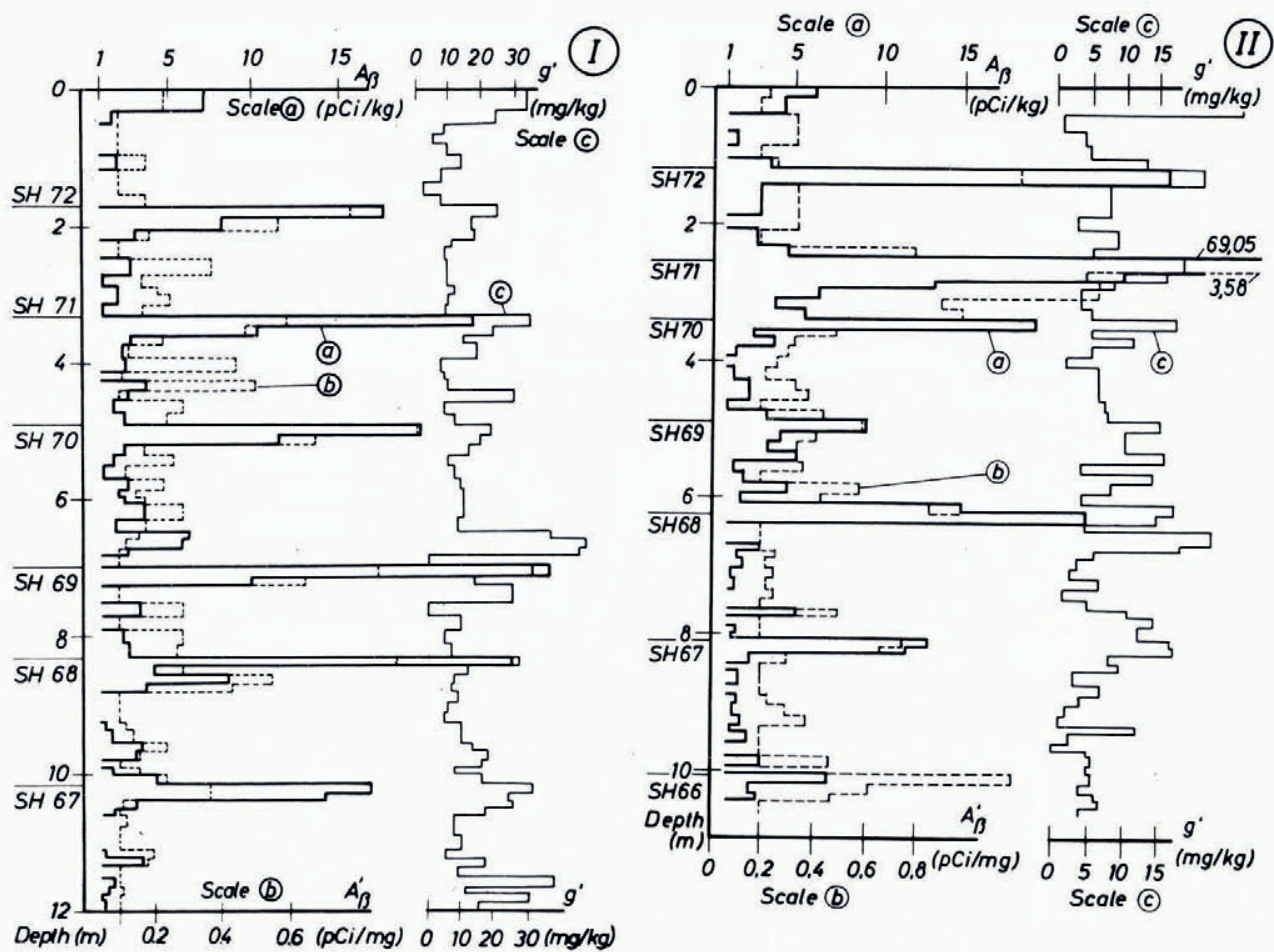

Fig. 12. Vertical profile of the gross beta actitity in the accumulation area of Kesselwandferner. 1: drilling I. $3225 \mathrm{~m}$ a.s.l., July 1973; II: drilling II, 3 I67 ma.s.l., July 1973; activity measurements: October 1973 to January 1974. SH= summer horizon.

Profile a: Specific beta activity $A_{\beta}(p C i / \mathrm{kg})$ of the firn sample; values $<I$ pCi $/ \mathrm{kg}$ have not been plotted.

Profile $b$ : Specific beta activity $A_{\beta}^{\prime}(p C i / m g)$ of the dry residue; values $<0.1$ and $0.2 p C i / m g$, respectively, have not been plotted.

Profile c: Specific dry residue $\mathrm{g}^{\prime}(\mathrm{mg} / \mathrm{kg})$ of the firn sample.

The value of the gross beta activity of a firn sample (units $\mathrm{pCi} / \mathrm{kg}$ ) may be given as the product of the following factors: $A_{\beta}{ }^{\prime}$ (units $\mathrm{pCi} / \mathrm{mg}$ ) and $g^{\prime}$ (units $\mathrm{mg} / \mathrm{kg}$ ), with $A_{\beta}{ }^{\prime}$ being the value of the specific gross beta activity related to the specific dry residue, and $g^{\prime}$ being the specific dry residue related to the mass of the firn sample. The depth profiles of $A_{\beta}^{\prime}$ and $g^{\prime}$ are plotted in Figure 12. In many cases the values of $A_{\beta}{ }^{\prime}$ and $g^{\prime}$ have a relative maximum in the summer horizons. This demonstrates that the peak values of the specific gross beta activity of the firn samples are accompanied by high values of $A_{\beta}{ }^{\prime}$ and $g^{\prime}$. Horizon analyses based on vertical profiles of $g^{\prime}$ alone are not clear.

These results confirm that the mechanism described by the model of infiltration and adsorption of radionuclides (Ambach and others, I968; Prantl and others, 1974) yields characteristic vertical profiles of gross beta activity in the accumulation area of an Alpine temperate glacier even during periods of low atmospheric fall-out. According to this model, summer ablation horizons are characterized by concentrated beta-active deposits that are bound to the horizons by adsorption. The percolating melt water does not wash-out this activity profile, but intensifies it secondarily, as the ablation horizon acts as an adsorption filter for the percolating melt water. 

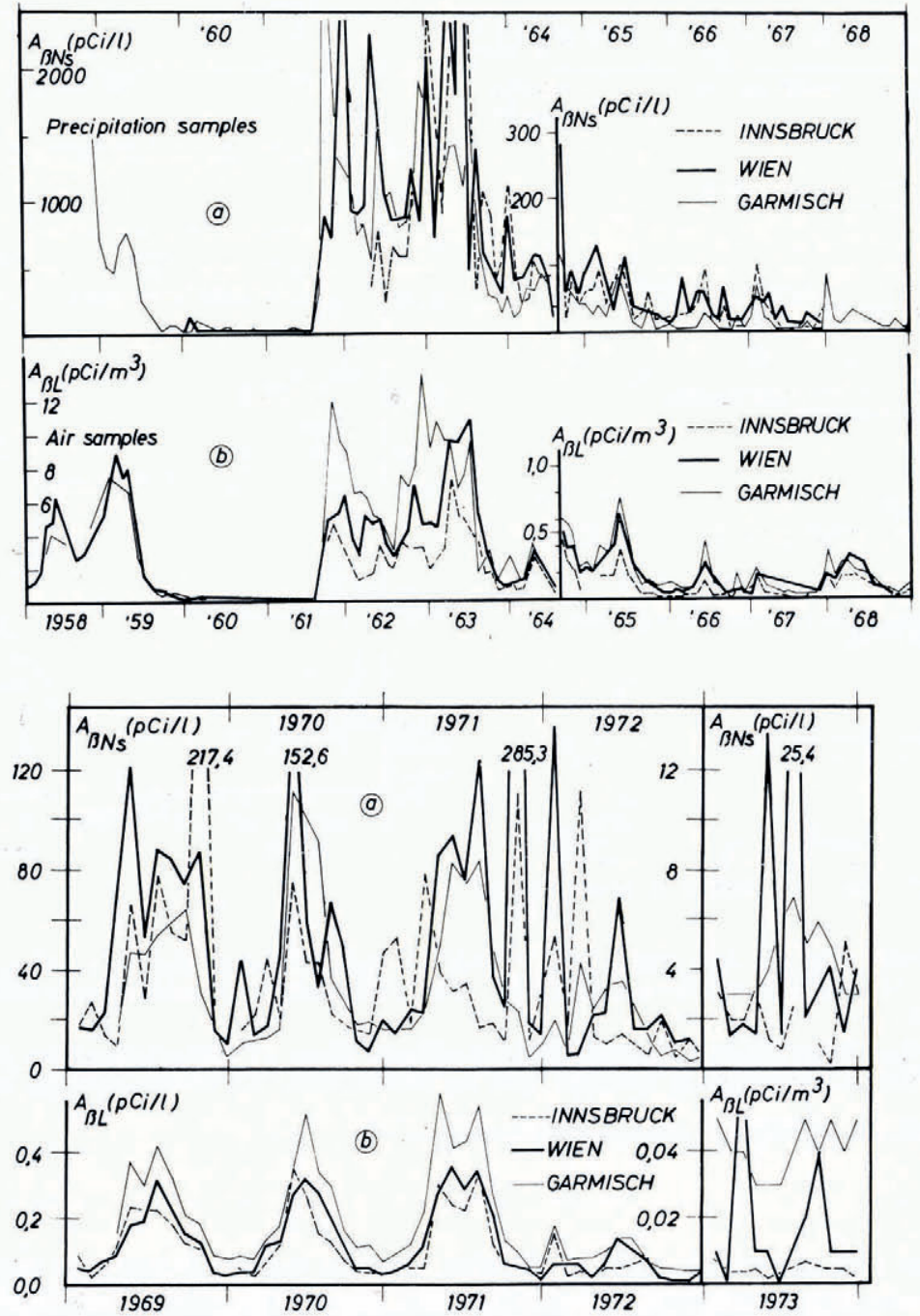

Fig. 13. Variation in gross beta activity for the years of 1.9 .58 to 1973.

(a) Precipitation samples $A_{\beta N S}(p C i / l)$;

(b) air sample $A_{\beta L}\left(p C i / m^{3}\right)$.

Station: Wien (Hohe Warte), Innsbruck (Hygienisches Institut der Universität Innsbruck), and Garmisch (top of Berg Wank). (The respective institutions are thanked for making data available.)

Control measurements of the activity values in horizons yielded an "apparent half-life" of about two years, in agreement with former measurements by Url (unpublished). This relatively. short "apparent half-life" of two years supports the assumption that the activity horizons are partly renewed by adsorption of short-lived nuclides, displaced from the snow surface by melt-water percolation.

In addition, the vertical distribution of tritium concentrations in a drill core from the neighboring drilling IV was studied. The decrease in tritium content upwards from a depth 
of $18 \mathrm{~m}$ was found to be in agreement with the gradual decrease in tritium concentrations in the precipitation of the past few years (Fig. I4). Relating the maximum tritium concentration of the profile with the accumulation in 1963 with its maximum tritium content in the precipitation, we obtain a mean annual net accumulation of $1.8 \mathrm{~m}$ of snow for the subsequent decade. This is in good agreement with horizon analyses from gross-beta-activity measurements in the drillings I and II covering the period of $1967-73$, and also with former examinations of tritium profiles covering the period of $1954-63$ made by Ambach and others (1969) in the vicinity of drilling IV.

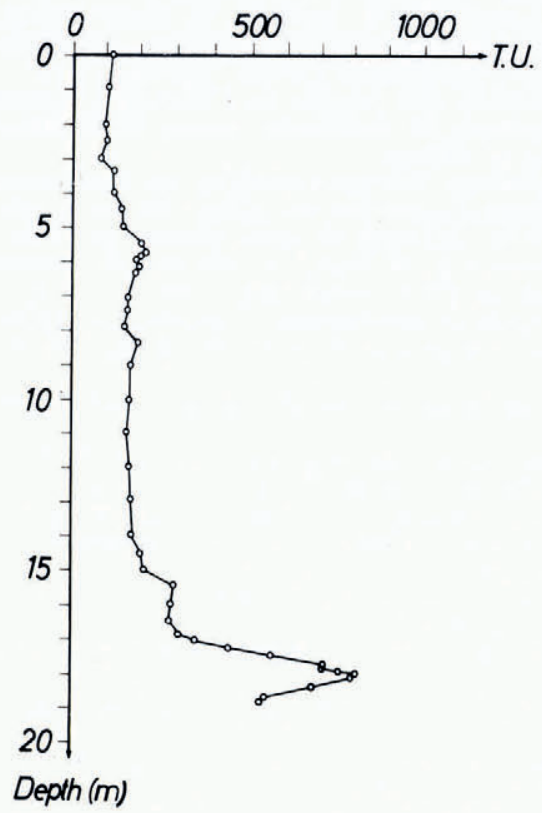

Fig. I4. Vertical profile of the tritium content in core IV (Kesselwandferner, $3227 \mathrm{~m}$ a.s.l., July 1973). The measured results refer to the date of sampling. The twofold standard deviations of the tritium concentrations are 3 to $7^{\circ} \circ$.

Consequently it was found that measurements of tritium content in firn layers yield a reference horizon characterized by an especially high tritium concentration in the vertical profile. This may be attributed to the net accumulation of $1962-63$. Adequate examination of the vertical distribution of gross beta activity in firn is a suitable means of analysing the net accumulation on Alpine glaciers, despite the low atmospheric fall-out of the past decade.

\section{AcKNOWLedgements}

We appreciate gratefully the financial support by the Österreichische Akademie der Wissenschaften, Wien, and the transportation of samples and material by the Bundesministerium für Inneres, Wien. We are grateful to all those who helped in field and laboratory work.

MS. received 8 October 1975 and in revised form 30 December 1975 


\section{REFERENCES}

Ambach, W., and others. 1968. Investigations of fission products in the accumulation area of an Alpine glacier (Kesselwandferner, Oetztal Alps), [by] W. Ambach, H. Eisner and F. A. Prantl. Union de Géodésie et Géophysique Internationale. Association Internationale d'Hydrologie Scientifique. Assemblée générale de Berne, 25 sept.-7 oct. 1967. [Commission de Neiges et Glaces.] Rapports et discussions, p. I 1 7-25.

Ambach, W., and others. Ig69. Tritium profiles in two firn cores from Alpine glaciers and tritium content in precipitation in the Alpine areas, [by] W. Ambach, H. Eisner and G. Sauzay. Archiv für Meteorologie, Geophysik und Bioklimatologie, Ser. B, Vol. 18, No. I, p. 93-104.

Ambach, W., and others. 1972. Isotopic oxygen composition of firn, old snow and precipitation in Alpine regions, by W. Ambach, H. Eisner and K. Pessl. Zeitschrift für Gletscherkunde und Glazialgeologie, Bd. 8, Ht. 1-2, p. 125-35.

Ambach, W., and others. 1973. Seasonal variations in the tritium activity of run-off from an Alpine glacier (Kesselwandferner, Oetztal Alps, Austria), by W. Ambach, H. Eisner and M. Url. Union Géodésique et Géophysique Internationale. Association Internationale d'Hydrologie Scientifique. Commission de Neiges et Glaces. Symposium on the Hydrology of Glaciers, Cambridge, 7-13 September 1969, p. 199-204.

Ambach, W., and others. 1975. Variationen des Gehaltes an Deuterium, Sauerstoff-1 8 und Tritium während einzelner Niederschläge, von W. Ambach, M. Elsässer, H. Moser, W. Rauert, W. Stichler und P. Trimborn. Wetter und Leben, Jahrg. 27, Ht. 3-4, p. $186-92$.

Bauer, F., and others. 1975. Ungewöhnliche Tritium-Verteilung im Niederschlag in den Ostalpen, [von] F. Bauer, V. Rajner und D. Rank. Naturwissenschaften, 62. Jahrg., Ht. I I, p. 526.

Behrens, H., and others. 1971. Study of the discharge of Alpine glaciers by means of environmental isotopes and dye tracers, by H. Behrens, H. Bergmann, H. Moser, W. Rauert, W. Stichler and W. Ambach, H. Eisner, K. Pessl. Zeitschrift für Gletscherkunde und Glazialgeologie, Bd. 7, Ht. 1-2, p. 79-102.

Bleeker, W., and others. 1966 . Some remarks on simultaneous measurements of particulate contaminants including radioactivity and isotopic composition of precipitation, by W. Bleeker, W. Dansgaard and W. N. Lablans. Tellus, Vol. 18, No. 4, p. $773-85$.

Craig, H. 1961. Standard for reporting concentrations of deuterium and oxygen-1 8 in natural waters. Science, Vol. 133 , No. 3467 , p. $1833-34$.

Ehhalt, D., and others. 1963 . Deuterium and oxygen 18 in rain water, [by] D. Ehhalt, K. Knott, J. F. Nagel, and J. C. Vogel. Fournal of Geophysical Research, Vol. 68, No. 13, p. 3775-80.

Eisner, H. I97I. Bestimmung der Firnrücklagenverteilung im Akkumulationsgebiet des Kesselwandferners (Ötztaler Alpen) durch Messung der Gesamt-Beta-Aktivität von Bohrproben. Zeitschrift für Gletscherkunde und Glazialgeologie, Bd. 7, Ht. 1-2, p. 65-78.

Elsässer, M. Unpublished. Umweltisotope und Farbstoffe als Tracer für schneehydrologische Untersuchungen. [Dr.phil. thesis, Universität Innsbruck, 1975.]

International Atomic Energy Agency (IAEA). 1971. Environmental isotope data, No. 3. Technical Report Series, No. 129 .

No. 129.
International Atomic Energy Agency (IAEA). 1973. Environmental isotope data, No. 4. Technical Report Series, No. 147 .

Judy, C., and others. 1970. Deuterium variations in an annual snowpack, by C. Judy and J. R. Meiman [and] I. Friedman. Water Resources Research, Vol. 6, No. 1, p. 125-29.

Martinec, J., and others. 1974. New insights into the run-off mechanism by environmental isotopes, [by] J. Martinec, U. Siegenthaler, H. Oeschger [and] E. Tongiorgi. (In Isotope techniques in groundwater hydrology 1974. Proceedings of a symposium organized by the International Atomic Energy Agency and held in Vienna, I1-15 March 1974. Vienna, International Atomic Energy Agency, Vol. I, p. 129-43.)

Moser, H., and Stichler, W. 1970. Deuterium measurements on snow samples from the Alps. (In Isotope hydrology 1970. Proceedings of a symposium on use of isotopes in hydrology held by the International Atomic Energy Agency in cooperation with the United Nations Educational, Scientific and Cultural Organization in Vienna, 9-13 March 1970. Vienna, International Atomic Energy Agency, p. 43-57.)

Moser, H., and Stichler, W. 1975. Deuterium and oxygen-18 contents as an index of the properties of snow covers. [Union Géodésique et Géophysique Internationale. Association Internationale des Sciences Hydrologiques. Commission des Neiges et Glaces.] Symposium. Mécanique de la neige. Actes du colloque de Grindelwald, avril 1974, p. 122-35.]

Prantl, F. A., and others. 1974. Alpine glacier studies with nuclear methods, [by] F. A. Prantl, W. Ambach and H. Eisner. (In [International Hydrological Decade.] The role of snow and ice in hydrology. Proceedings of the Banff symposia, September 1972. Paris, UNESCO; Geneva, WMO; Budapest, IAHS, Vol. I, p. 435-44.)

Reinwarth, O. 1972. Untersuchungen zum Massenhaushalt des Vernagtferners (Ötztaler Alpen) 1965-1968. Zeitschrift für Gletscherkunde und Glazialgeologie, Bd. 8, Ht. 1-2, p. 43-63.

Url, M. Unpublished. Glazialhydrologische Untersuchungen mit Tritium und radioaktiven Spaltprodukten. [Dr.phil. thesis, Universität Innsbruck, 1970.] 